\title{
STUDI PENERAPAN E-GOVERNMENT DI INDONESIA DAN NEGARA LAINNYA SEBAGAI SOLUSI PEMBERANTASAN KORUPSI DI SEKTOR PUBLIK
}

(Implementation Study on E-Government in Indonesia and Other Countries As A Solution in Eradicating Corruption in Public Sector)

\author{
Loura Hardjaloka \\ Associates Bahar \& Partners \\ Jl. Dr. Ide Anak Agung Gde Agung Blok 6.2, Kawasan Mega Kuningan, Jakarta Selatan \\ Email: loura.hardjaloka@gmail.com atau loura@baharandpartners.com
}

Naskah diterima: 13 Oktober 2014; revisi: 20 Nopember 2014; disetujui: 28 Nopember 2014

\begin{abstract}
Abstrak
Saat ini banyak Negara termasuk Indonesia fokus menggunakan e-government sebagai salah satu perangkat utama untuk melawan korupsi. Berdasarkan hal tersebut, tulisan ini membahas konsep e-government serta studi perbandingan implementasi e-government yang diterapkan di Indonesia dan Negara lainnya. Adapun penelitian ini dilakukan melalui penelitian hukum normatif dan analisis kualitatif sehingga menghasilkan penelitian yang deskriptif. Berdasarkan hasil penelitian, diketahui bahwa banyak Negara termasuk Indonesia menerapkan e-government dalam berbagai bentuk untuk meningkatkan prinsip-prinsip good governance dalam rangka memberantas korupsi, diantaranya pengadaan barang dan jasa, perpajakan, dan juga perizinan. Meskipun demikian, masih banyak hal yang perlu diperbaiki oleh Indonesia dalam menerapkan e-government, antara lain percepatan pembuatan peraturan perundang-undangan dan kebijakan untuk mendukung e-government di daerah; pengadaan sarana-prasarana pengembangan infrastruktur untuk menciptakan akses komunikasi data yang handal; pemberdayaan sumber daya manusia; pengembangan perangkat lunak yang diperlukan; dan pengembangan organisasi dan tata kerja yang mendukung e-government.
\end{abstract}

Kata Kunci: e-government, korupsi, studi perbandingan

\section{Abstract}

Nowadays many countries including Indonesia focuses on using e-government as one of the main tools to fight corruption. Based on that, this article will discuss e-government concepts and comparative studies of e-government implementation in Indonesia and other countries. This research using normative legal research and qualitative analysis thus produced the descriptive study. This research found that many countries including Indonesia are implementing e-government in various forms to improve the good governance principles in order to eradicate corruption such as procurement process, taxation, and licensing. Nonetheless, there are many things need to be fixed by Indonesia in implementing e-government specifically the acceleration of making laws and policies to support e-government in the region; procurement of infrastructure development to create reliable data communications access; empowerment of human resources; adjustable software development; and development of the organization and working procedures that support e-government.

Keywords: e-government, corruption, comparative study 


\section{A. Pendahuluan}

Berdasarkan survei Corruption Perceptions Index 2013 mengenai tingkat korupsi di suatu Negara yang dilakukan oleh Transparency International (TI), secara global terdapat 6 (enam) Negara yang memiliki tingkat korupsi rendah dari 175 negara yang dilakukan survei, yaitu Denmark, Finlandia, Selandia Baru, Swedia, Norwegia, dan Singapura, sedangkan Indonesia sendiri berada pada posisi $114 .{ }^{1}$

Menurut Klitgaard ketika pemerintah sebagai pelayan masyarakat memiliki kekuatan monopoli yang besar atas warga, memiliki tingkat diskresi yang besar, dan lemahnya akuntabilitas maka akan timbul yang namanya korupsi. ' Selanjutnya, menurut Paul melalui studinya memperlihatkan bahwa monopoli, diskresi, dan minimnya akuntabilitas menjadi faktor-faktor kunci timbulnya korupsi di sektor publik. ${ }^{3}$ Secara singkat, faktor-faktor tersebut dirumuskan ialah sebagai berikut:

\section{KORUPSI = MONOPOLI + DISKRESI - AKUNTABILITAS}

Pertama, adanya kekuatan monopoli yang dimiliki oleh pemerintah untuk dapat mengendalikan atau mengakses sumber daya alam atau sumber daya manusia serta peraturan perundang-undangan. Menurut
Zemanovicova, monopoli dalam pelayanan publik dengan skala besar terjadi ketika adanya ketidakseimbangan antara permintaan dan penawaran dalam pelayanan publik dan adanya eksklusifitas dalam memberikan akses atas informasi, sehingga diperlukan kemampuan untuk meminimalisasikan pengendalian tersebut melalui desentralisasi tugas. ${ }^{4}$ Sejalan dengan hasil penelitian yang dilakukan oleh Emerson, bahwa dalam suatu pasar yang aksesnya dibatasi oleh pemerintah maka pihak yang memiliki kekuasaan untuk memberikan akses akan cenderung melakukan korupsi dengan cara menentukan jumlah uang suap yang harus dibayarkan oleh para perusahaan yang hendak masuk ke dalam pasar tersebut. ${ }^{5}$ Dengan demikian, untuk meminimalisasi korupsi dan minimnya transparansi tersebut, para ilmuwan merekomendasikan untuk pelaksanaan e-government untuk meningkatkan transparansi dan membuka akses atas informasi tentang pemerintah. ${ }^{6}$

Kedua, adanya diskresi (wewenang) yang dimiliki oleh pejabat publik membuka peluang untuk disalahgunakan melakukan korupsi seperti adanya pungutan liar dalam pengurusan perizinan. Hal ini terjadi dikarenakan adanya prosedur yang kompleks dan proses yang panjang sehingga membuat masyarakat cenderung mengambil jalan pintas. Melihat adanya dukungan dari internal pemerintah 
dan cenderung ingin cepat maka masyarakat lebih memilih untuk membayar lebih mahal kepada pegawai pemerintah tersebut. Terdapat langkah-langkah yang dapat dilakukan untuk mengurangi adanya penyalahgunaan wewenang dan korupsi, yaitu (i) mempersingkat proses perizinan ${ }^{7}$ dan penyederhanaan jumlah perizinan; ${ }^{8}$ dan (ii) menghadirkan e-government sebagai salah satu perangkat yang dapat mengurangi penggunaan diskresi oleh pejabat publik mengingat teknologi akan membuat proses pengurusan menjadi lebih transparan, mudah, dan tidak dapat diintervensi oleh pejabat publik. ${ }^{9}$

Ketiga, minimnya akuntabilitas dapat terlihat dari cara pengambilan keputusan dan tindakan yang dilakukan oleh pejabat publik dan hal tersebut dapat diatasi melalui teknologi informasi dan komunikasi. Lebih lanjut, akuntabilitas terbagi atas 3 komponen penting, yaitu: (i) partisipasi warga Negara dalam proses politik dan pemerintahan; (ii) birokrasi yang efektif; dan (iii) implementasi peraturan perundang-undangan. Menurut Charron et.al., proses pemilihan umum sebagai bentuk dalam partisipasi politik dan pemerintahan merupakan bentuk efektif dalam meminimalisir korupsi dalam pemerintahan dikarenakan pejabat yang korupsi cenderung akan masuk daftar hitam dan tidak akan dipilih kembali. ${ }^{10}$ Selanjutnya, Marc Cools et.al., berdasarkan studinya menunjukan bahwa korupsi dapat diberantas apabila pejabat dipilih berdasarkan kompetisi pemilihan umum yang kuat. ${ }^{11}$ Di samping itu, menurut kajian yang dilakukan OECD bahwa untuk meningkatkan efisiensi dan akuntabilitas para pejabat maka dibutuhkan e-government sehingga masyarakat yang memilih pejabat tersebut dapat memantau kinerja para pejabat secara mudah. ${ }^{12}$

E-government merujuk kepada penggunaan teknologi khususnya internet dan teknologi komunikasi serta World Wide Web (www) dalam menyelenggarakan pelayanan pemerintah secara elektronik kepada masyarakat, dunia usaha, organisasi, dan lainnya. Dahulu penggunaaan e-government masih sebatas percobaan akan tetapi saat ini justru sebagai sarana terpenting dalam transformasi pelayanan di sektor publik. ${ }^{13}$ Penggunaan perangkatperangkat teknologi yang modern di sektor publik dapat memberikan hasil pelayanan yang berbeda kepada pengguna jasa, seperti (i) pelayanan jasa dan informasi yang lebih baik kepada warga masyarakat, (ii) interaksi efektif

$7 \quad$ Clarke D. Forsythe, Abuse of Discretion: The Inside Story of Roe v. Wade (New York: Wilsted \& Taylor Publishing Services, 2013), hlm. 320.

8 D. Kaufmann, A.Kraay, and M. Mastruzzi, Governance Matters VIII: Aggregate and Individual Governance Indicators, 1996-2008 (United States: Development Research Group Macroeconomics and Growth Team The World Bank: 2010), hlm. 3.

9 J. Martinez-Vazquez, Arze del Granado, and J. Boex, Fighting Corruption in The Public Sector (London: Elsevier, 2012), hlm. 250.

10 Nicholas Charron, Victor Lapuente, and Bo Rothstein, Quality of Government and Corruption from a European Perspective: A Comparative Study of Good Government in EU Regions (United Kingdom: Edward Elgar Publishing Limited, 2013), hlm. 145.

11 Marc Cools et.al., EU Criminal Justice, Financial, and Economic Crime (Poland: Maklu Publishers, 2011), hlm. 48.

12 OECD, OECD E-Government Studies: Egypt 2012 (Egypt: OECD Publishing, 2013), hlm. 71.

13 United Nations, United Nations E-Government Survey 2014: E-Government for the Future We Want (New York: Bern Assoc, 2014), hlm. 155. 
dengan pelaku usaha; (iii) pemberdayaan masyarakat melalui akses informasi; atau (iv) manajemen pelayanan sektor publik yang efektif dan efisien. Selain itu, penggunaan teknologi melalui e-government diharapkan dapat meningkatkan transparansi, pertumbuhan pendapat, mengurangi penggunaan biaya, dan yang terpenting ialah memberantas korupsi. ${ }^{14}$

Belakangan ini, telah ada banyak Negara termasuk Indonesia yang fokus dalam menggunakan e-government untuk memberikan akses yang besar dan mudah kepada masyarakat terhadap proses pelayanan publik dan kinerja pemerintahan, sebagai salah satu perangkat utama untuk melawan korupsi. ${ }^{15}$ Berdasarkan latar belakang tersebut, tulisan ini akan membahas mengenai bagaimana konsep e-government dan korupsi; dan bagaimana penerapan e-government di Indonesia dan Negara lainnya dalam rangka memberantas korupsi.

\section{B. Metode Penelitian}

\section{Sifat Penelitian}

Penelitian ini adalah penelitian hukum normatif yang dilakukan menggunakan penelitian kepustakaan untuk mendapatkan data sekunder dengan bahan atau materi berupa buku-buku, artikel-artikel, hasil-hasil penelitian, dan pendapat ahli yang berkaitan dengan penerapan e-government di Indonesia dan Negara lainnya dalam rangka memberantas korupsi.

\section{Metode Pengumpulan Data}

Pengumpulan data dilakukan dengan studi dokumen dan literatur-literatur yang berkaitan dengan tema penelitian untuk mendapatkan data berkaitan dengan penerapan e-government di Indonesia dan Negara lainnya dalam rangka memberantas korupsi, sebagai berikut:

a. Bahan Primer, yang mencakup peraturan perundang-undangan yang berlaku, yurisprudensi yang berkaitan dengan pokok permasalahan penelitian.

b. Bahan Sekunder, terdiri dari hasil-hasil penelitian yang telah ada sebelumnya yang terkait dengan permasalahan penelitian dan kepustakaan, termasuk bahan dan hasil seminar dan konferensi-konferensi;

c. Bahan Tersier, yang terdiri dari kamus hukum, ensiklopedia dan kamus pendukung lainnya.

\section{Metode Analisis Data}

Berdasarkan data dan informasi yang sudah diperoleh, akan dilakukan analisis kualitatif yakni suatu cara penelitian yang menghasilkan data deskriptif analitis, yaitu apa yang ditemukan dalam praktek dan literatur diteliti dan dipelajari sebagai sesuatu yang utuh.

\section{Pembahasan}

\section{Konsep E-Government}

a. Pengertian

Menurut Bank Dunia, "e-government refers to the use by government agencies of information

Paul G. Nixon, Vassiliki N. Koutrakou, and Rajash Rawal, Understanding E-Government in Europe: Issues and Challenges, (New York: Routridge, 2010), hlm. 131.

15 Sushil Kumar Singla, Himanshu Anggarwal, "Combating Corruption Through E-Governance in Public Service Delivery System," Journal of Global Research in Computer Science 2 (2011): 96. 
technologies (such as Wide Area Network, the internet, and mobile computing) that have the ability to transform relations with citizens, business, and other arms of government."16 Berdasarkan definisi tersebut, e-government merujuk pada teknologi informasi di lembaga pemerintah atau lembaga publik. Tujuannya adalah agar hubungan dalam tata pemerintahan (governance) yang melibatkan pemerintah, pelaku bisnis dan masyarakat dapat tercipta lebih efisien, efektif, produktif dan responsif. Dengan demikian, hasil yang diperoleh melalui e-government, yaitu terciptanya pemerintahan yang baik korupsi yang berkurang, transparansi yang meningkat, kenyamanan yang lebih besar, peningkatan penerimaan negara, dan/atau pengurangan biaya.
Berdasarkan definisi di atas, e-government melahirkan 4 model hubungan sebagai berikut:

Gambar 1. Model Hubungan E-Government

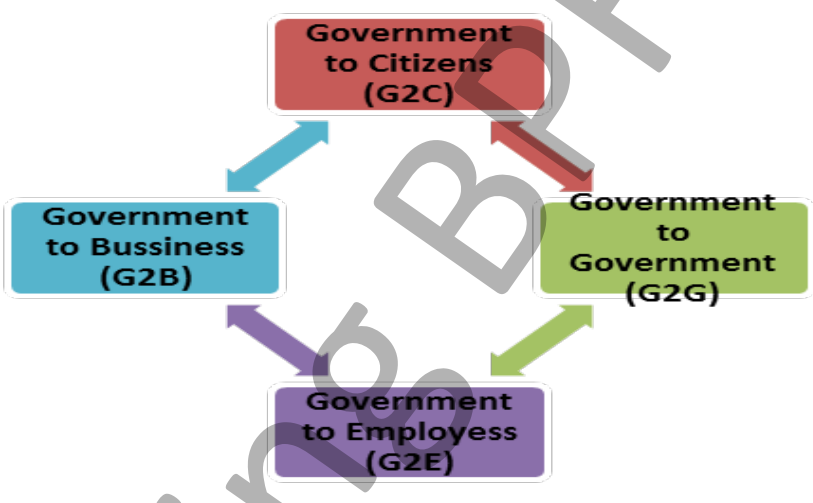

Sumber: Diolah oleh Penulis

Adapun penjelasan atas gambar di atas dijabarkan sebagai berikut: ${ }^{17}$

Tabel 1. Deskripsi Model Hubungan E-Government

\begin{tabular}{|c|c|c|c|}
\hline No. & Jenis Hubungan & Deskripsi & Contoh Aplikasi \\
\hline 1 & $\begin{array}{l}\text { Government to } \\
\text { Citizen }\end{array}$ & $\begin{array}{l}\text { Merupakan layanan e-government dimana pemerintah } \\
\text { membangun dan menerapkan pelayanan menggunakan } \\
\text { teknologi informasi yang bertujuan untuk memperbaiki } \\
\text { hubungan interaksi pemerintah dengan masyarakat } \\
\text { (rakyat). Dengan kata lain, tujuan utama dari dibangunnya } \\
\text { aplikasi ini adalah untuk mendekatkan pemerintah } \\
\text { dengan rakyatnya melalui kanal-kanal akses yang beragam } \\
\text { agar masyarakat dapat dengan mudah menjangkau } \\
\text { pemerintahnya untuk pemenuhan berbagai kebutuhan } \\
\text { pelayanan sehari-hari. }\end{array}$ & $\begin{array}{l}\text { Kepolisian membuka jasa pelayanan perpanjangan Surat } \\
\text { ljin Mengemudi (SIM) atau Surat Tanda Nomor Kendaraaan } \\
\text { (STNK) melalui online sehingga dapat mempermudah } \\
\text { administrasi dari pemilik kendaraan, mempercepat } \\
\text { proses, dan menghindari pungutan liar. }\end{array}$ \\
\hline 2 & $\begin{array}{l}\text { Government to } \\
\text { Business }\end{array}$ & $\begin{array}{l}\text { Merupakan layanan e-government dimana pemerintah } \\
\text { membangun dan menerapkan pelayanan dengan } \\
\text { menggunakan teknologi informasi yang bertujuan } \\
\text { untuk mempermudah interaksi antara badan usaha dan } \\
\text { pemerintah. }\end{array}$ & $\begin{array}{l}\text { - Proses pengadaan barang/jasa di lembaga } \\
\text { pemerintahan dapat dilakukan dengan menggunakan } \\
\text { e-procurement sehingga proses pengadaan dapat } \\
\text { dilakukan secara efektif, efisien, meminimalisir korupsi, } \\
\text { dan persaingan usaha tidak sehat diterapkan. } \\
\text { - Pembayaran pajak oleh badan usaha dilakukan melalui } \\
\text { aplikasi berbasis website sehingga meminimalisir waktu } \\
\text { dan korupsi di bidang perpajakan. }\end{array}$ \\
\hline
\end{tabular}

Maja Klun, et.al., Proceedings of the $11^{\text {th }}$ European Conference on E-Government (United Kingdom: Academic Conferences and Publishing International Limited, 2011), hlm. 11.

17 Jesper Schalaeger, E-Government in China: Technology, Power, and Local Government Reform (New York: Routledge, 2013), hlm. 8-20. 


\begin{tabular}{|c|c|c|c|}
\hline No. & Jenis Hubungan & Deskripsi & Contoh Aplikasi \\
\hline & $\begin{array}{l}\text { Government to } \\
\text { Government }\end{array}$ & $\begin{array}{l}\text { Di era globalisasi ini terlihat jelas adanya kebutuhan bagi } \\
\text { negara-negara untuk saling berkomunikasi secara lebih } \\
\text { intens dari hari ke hari. Kebutuhan untuk berinteraksi } \\
\text { antar satu pemerintah dengan pemerintah setiap harinya } \\
\text { tidak hanya berkisar pada hal-hal yang berkaitan dengan } \\
\text { diplomasi namun lebih jauh daripada itu yaitu untuk } \\
\text { memperlancar kerjasama antar negara seperti dalam } \\
\text { melakukan hal-hal yang berkaitan dengan administrasi } \\
\text { perdagangan, proses-proses politik, mekanisme hubungan } \\
\text { sosial dan budaya, dan lain sebagainya. }\end{array}$ & $\begin{array}{l}\text { - Aplikasi yang dapat menghubungkan antara kantor- } \\
\text { kantor pemerintah setempat dengan sejumlah } \\
\text { kedutaan-kedutaan besar atau konsulat jenderal untuk } \\
\text { membantu penyediaan data dan informasi akurat yang } \\
\text { dibutuhkan oleh para warga negara asing yang sedang } \\
\text { berada di Indonesia. } \\
\text { - Pengembangan suatu sistem data intelijen yang } \\
\text { berfungsi untuk mendeteksi orang-orang yang tidak } \\
\text { boleh masuk atau keluar dari suatu wilayah Negara. }\end{array}$ \\
\hline & $\begin{array}{l}\text { Government to } \\
\text { Employees }\end{array}$ & $\begin{array}{l}\text { Aplikasi e-Government juga diperuntukkan untuk } \\
\text { meningkatkan kinerja dan kesejahteraan para pegawai } \\
\text { negeri atau karyawan pemerintahan yang bekerja di } \\
\text { sejumlah institusi sebagai pelayan masyarakat. }\end{array}$ & $\begin{array}{l}\text { - Aplikasi terpadu untuk mengelola berbagai tunjangan } \\
\text { kesejahteraan pegawai pemerintahan. } \\
\text { - Sistem asuransi kesehatan dan pendidikan bagi para } \\
\text { pegawai pemerintahan yang telah terintegrasi dengan } \\
\text { lembaga-lembaga kesehatan (rumah sakit, poliklinik, } \\
\text { apotik, dan lain sebagainya) dan institusi-institusi } \\
\text { pendidikan (sekolah, perguruan tinggi, kejuruan, dan } \\
\text { lain-lain). }\end{array}$ \\
\hline
\end{tabular}

Sumber: Schalaeger

Banyak model-model yang dikemukakan oleh ahli untuk mengidentifikasi suatu tahapan penerapan e-government di suatu negara, sebagai berikut:

Tabel 2. Model Tahapan E-Government ${ }^{18}$

\begin{tabular}{|c|c|c|c|c|c|c|}
\hline Model & Tahap I & Tahap II & Tahap III & Tahap IV & Tahap V & Tahap VI \\
\hline Layne \& Lee & Catalogue & Transaction & Vertical Integration & $\begin{array}{l}\text { Horizontal } \\
\text { Integration }\end{array}$ & NA & NA \\
\hline $\begin{array}{l}\text { Andersen and } \\
\text { Henriksen }\end{array}$ & Cultivation & Extension & Maturity & Revolution & NA & NA \\
\hline United Nation & $\begin{array}{c}\text { Emerging } \\
\text { information } \\
\text { services } \\
\end{array}$ & $\begin{array}{c}\text { Enhanced } \\
\text { information } \\
\text { services }\end{array}$ & Interactive & Transactional & Fully Integrated & NA \\
\hline Alhomod et al. & $\begin{array}{c}\text { Presence on the } \\
\text { web }\end{array}$ & $\begin{array}{l}\text { Interaction } \\
\text { between the } \\
\text { citizen and the } \\
\text { government }\end{array}$ & $\begin{array}{c}\text { Complete } \\
\text { transaction over } \\
\text { the web }\end{array}$ & $\begin{array}{l}\text { Integration of } \\
\text { services }\end{array}$ & NA & NA \\
\hline $\begin{array}{l}\text { Hiller and } \\
\text { Belanger }\end{array}$ & Information & $\begin{array}{c}\text { Two way } \\
\text { communication }\end{array}$ & Transaction & Integration & Participation & NA \\
\hline $\begin{array}{l}\text { Almazan and Gil- } \\
\text { Garcia }\end{array}$ & Presence & Information & Interaction & Transaction & Integration & $\begin{array}{c}\text { Political } \\
\text { Participation }\end{array}$ \\
\hline Cisco & $\begin{array}{l}\text { Information } \\
\text { interaction }\end{array}$ & $\begin{array}{c}\text { Transaction } \\
\text { efficiency }\end{array}$ & $\begin{array}{c}\text { Transformation } \\
\text { citizen centric }\end{array}$ & NA & NA & NA \\
\hline Gartner group & Web presence & Interaction & Transaction & Transformation & NA & NA \\
\hline West & Bill-board & $\begin{array}{l}\text { Partial-service- } \\
\text { delivery }\end{array}$ & Portal & $\begin{array}{l}\text { Interactive } \\
\text { democracy }\end{array}$ & NA & NA \\
\hline
\end{tabular}

Abdoullah Fath-Allah et.al., "E-Government Maturity Models: A Comparative Study", International Journal of Software Engineering and Applications (IJSEA) 5 (2014): 81. 


\section{R Junah HTSVINDING}

Media Pembinaan Hukum Nasional

Volume 3 Nomor 3, Desember 2014

\begin{tabular}{|c|c|c|c|c|c|c|}
\hline Model & Tahap I & Tahap II & Tahap III & Tahap IV & Tahap V & hap VI \\
\hline Moon & $\begin{array}{l}\text { Simple information } \\
\text { dissemination }\end{array}$ & $\begin{array}{c}\text { Two-way } \\
\text { communication }\end{array}$ & $\begin{array}{l}\text { Service and } \\
\text { financial } \\
\text { transactions }\end{array}$ & Integration & $\begin{array}{c}\text { Political } \\
\text { Participation }\end{array}$ & \\
\hline World Bank & Publish & Interact & Transaction & NA & NA & NA \\
\hline $\begin{array}{l}\text { Deloitte and } \\
\text { Touche }\end{array}$ & $\begin{array}{l}\text { Information } \\
\text { publishing }\end{array}$ & $\begin{array}{l}\text { Official-two way } \\
\text { transactions }\end{array}$ & $\begin{array}{l}\text { Multipurpose } \\
\text { portals }\end{array}$ & $\begin{array}{c}\text { Portal } \\
\text { Personalization }\end{array}$ & $\begin{array}{c}\text { Clustering of } \\
\text { common services }\end{array}$ & $\begin{array}{c}\text { Full integration } \\
\text { and enterprise } \\
\text { transaction }\end{array}$ \\
\hline Howard & Publish & Interact & Transaction & NA & NA & NA \\
\hline Shahkooh et al. & Online presence & Interaction & Transaction & $\begin{array}{l}\text { Fully integrated } \\
\text { and transformed } \\
\text { e- government }\end{array}$ & Digital democracy & NA \\
\hline Lee and Kwak & Initial conditions & Data transparency & Open participation & Open collaboration & $\begin{array}{l}\text { Ubiquitous } \\
\text { engagement }\end{array}$ & NA \\
\hline Siau and Long & Web presence & Interaction & Transaction & Transformation & E-democracy & NA \\
\hline Wescott & $\begin{array}{c}\text { Setting up an email } \\
\text { system and internal } \\
\text { network }\end{array}$ & $\begin{array}{l}\text { Enabling inter- } \\
\text { organizational and } \\
\text { public access to } \\
\text { information }\end{array}$ & $\begin{array}{l}\text { Allowing two way } \\
\text { communication }\end{array}$ & Exchange of value & Digital democracy & $\begin{array}{l}\text { Joined-up } \\
\text { government }\end{array}$ \\
\hline $\begin{array}{l}\text { Chandler and } \\
\text { Emanuel }\end{array}$ & Information & Interaction & Transaction & Integration & NA & NA \\
\hline Kim and Grant & Web presence & Interaction & Transaction & Integration & $\begin{array}{c}\text { Continuous } \\
\text { Improvement }\end{array}$ & NA \\
\hline Chen et al. & Catalogue & Transaction & Vertical Integration & NA & NA & NA \\
\hline Windley & Simple Web site & Online government & $\begin{array}{l}\text { Integrated } \\
\text { government }\end{array}$ & $\begin{array}{c}\text { Transformed } \\
\text { government }\end{array}$ & NA & NA \\
\hline Reddick & Cataloguing & Transactions & NA & NA & NA & NA \\
\hline Accenture & Online presence & Basic capability & Service availability & Mature delivery & $\begin{array}{c}\text { Service } \\
\text { transformation }\end{array}$ & NA \\
\hline $\begin{array}{l}\text { The UK National } \\
\text { Audit }\end{array}$ & Basic site & $\begin{array}{l}\text { Electronic } \\
\text { publishing }\end{array}$ & E-publishing & Transactional & $\begin{array}{c}\text { Joined-up e- } \\
\text { governance }\end{array}$ & NA \\
\hline $\begin{array}{l}\text { E-government } \\
\text { Indonesia }\end{array}$ & Preparation & Maturation & Consolidation & Utilization & NA & NA \\
\hline
\end{tabular}

Sumber: Abdoullah Fath-Allah, Laila Cheikhi, Rafa E. Al-

Qutaish, and Ali Idri

\section{b. Beberapa Tahapan}

Berdasarkan tabel di atas dapat dijelaskan secara umum bahwa tahapan tingkat perkembangan e-government adalah sebagai berikut:

\section{1) Emergence}

Pada tahap ini dapat dilihat bahwa keseluruhan model memiliki kesamaan konsep yakni menggunakan website sebagai sarana untuk mempublikasikan informasi namun data dan informasi yang dipublikasikan tidak lebih dari sekedar visi, misi, dan aktivitas organisasi pemerintah tersebut. ${ }^{19}$ Adapun dalam tahap ini, website masih menjadi sarana komunikasi satu arah dan belum terdapat interaksi secara elektronik antara pemerintah dan masyarakat ataupun adanya tautan yang menghubungkan ke website lembaga pemerintah lainnya. ${ }^{20}$ 


\section{2) Enhance}

Dalam tahap ini, sistem e-government telah lebih dikembangkan dengan cara memberikan tautan yang menghubungkan dengan informasi-informasi tertentu berupa formulir perizinan, dokumen, laporan, peraturan, atau newsletters. ${ }^{21}$ Adapun publikasi atas informasi melalui elektronik dapat mengurangi jumlah pegawai negeri yang seharusnya melayani masyarakat untuk memberikan informasi tersebut. Untuk tetap menjaga kemutakhiran informasi, masa masing-masing lembaga pemerintah harus memperbaharui informasi minimal 3 (tiga) bulan sekali. ${ }^{22}$

\section{3) Interaksi}

Pada tahap interaksi, halaman situs yang disajikan pemerintah tidak sekedar menyajikan paparan dan informasimengenai keberadaannya secara online, tetapi juga disertai fasilitas komunikasi secara elektronik (e-mail) sehingga dapat tercipta komunikasi dua arah antara pemerintah dan masyarakat. ${ }^{23}$ Kebanyakan situs yang dibangun oleh pemerintah Indonesia baru memasuki tahap interaksi. Penyajian fasilitas e-mail ini dimaksudkan untuk memberikan titik kontak penyaji situs dan pengunjung situs serta memungkinkan pengunjung situs menggali informasi yang lebih mendalam tentang berbagai macam hal yang terkait dengan keberadaan penyaji situs. Dengan adanya halaman situs yang dapat menciptakan komunikasi dua arah seperti ini dapat meningkatkan responsifitas pemerintah terhadap masyarakat. ${ }^{24}$

\section{4) Transaksi}

Pada tahap ini layanan yang diberikan pemerintah melalui halaman situs tidak sebatas informasi mengenai organisasi pemerintah yang bersangkutan secara online dan fasilitas komunikasi melalui e-mail tetapi juga melayani kebutuhan lain dalam 24 (dua puluh empat) jam sepanjang hari seperti pembuatan, perpanjangan, atau pembaharuan perijinan, passport, kartu identitas tertentu atau yang lainnya, beserta pelaksanaan pembayarannya. ${ }^{25}$

Oleh karena itu, tahap ini mensyaratkan validitas situs termasuk keamanannya, terutama keamanan untuk proses approval dari pihak pemerintah. Proses approval harus dipastikan hanya dilakukan oleh pejabat pemerintah yang memang secara struktur memiliki kewenangan untuk melakukannya.

\section{5) Transformasi/Terintegrasi}

Pada tahap ini, seluruh lembaga pemerintah telah terintegrasi dalam satu halaman situs sehingga suatu halaman situs dapat menjadi one stop service bagi masyarakat serta masyarakat dapat turut berpartisipasi dalam kegiatan

${ }_{21}$ Zaigham Mahmood, E-Government Implementation and Practice in Developing Countries (United States: Information Science Reference, 2013), hlm. 360.

22 J. Ramon Gil-Garcia, Enacting Electronic Government Success: An Integrative Study of Government -wide Websites, Organizational Capabilities, and Institutions (New York: Springer, 2012), hlm. 17-18.

23 Mahmud Akhter Shareef, et.al., Transformational Government Through eGov Practice: Socioeconomic, Cultural, and Technological Issues (United Kingdom: Emerald Group Publishing Limited, 2012), hlm. 95-114.

24 M. Snellen, M. Thaens, and J.van de Honk, Public Administration in The Information Age: Revisited (Netherlands: IOS Press BV, 2012), hlm. 31-36.

25 Mahmud Akhter Shareef, Stakeholder Adoption of E-Government Services: Driving and resisting Factors (New York: IGI Global Snippet, 2011), hlm. 27-35. 
pemerintahan dilakukan dengan secara online untuk meningkatkan transparansi, efisiensi, kualitas layanan publik, pengembangan ekonomi dan memberantas korupsi. Lebih lanjut, tahap transformasi ini membutuhkan teknologi yang tinggi, tingkat keamanan yang tinggi serta keterbukaan pihak pemerintah untuk mempublikasikan informasi.

\section{c. Peluang E-Government}

Terdapat beberapa peluang dengan diterapkannya e-government. Beberapa di antaranya adalah:

1) Meningkatkan Efektifitas, Efisiensi, dan Mengurangi Biaya

Dengan menerapkan e-government dapat meningkatkan efektifitas dan efisiensi dalam pelayanan publik melalui layanan yang tepat waktu, cepat, dan pelayanan yang merata kepada seluruh pengguna layanan tanpa diskriminasi. Hal ini dikarenakan e-government menggunakan aplikasi berbasis internet yang dapat melakukan pengumpulan, transmisi, penyediaan data dan komunikasi dengan pengguna secara cepat. Dengan adanya pelayanan publik yang efektif dan efisien maka akan mengurangi biaya operasional pemerintah.

\section{2) Meningkatkan Pelayanan}

Layanan publik yang fokus pada pengguna layanan merupakan inti dari reformasi pelayanan publik saat ini. Dalam rangka meningkatkan pelayanan kepada pengguna layanan maka harus dilakukan integrasi e-government antar lembaga pemerintahan baik di tingkat pusat ataupun daerah. Dengan adanya integrasi maka pengguna layanan dapat mengakses satu website untuk seluruh jenis layanan yang dibutuhkan oleh pengguna layanan.

\section{3) Meningkatkan Partisipasi Masyarakat}

Semua warga masyarakat mempunyai hak untuk berpendapat dan dengan menerapkan e-government maka masyarakat dapat berpartisipasi dalam memberikan saran dan masukan dalam rangka peningkatan pelayanan pemerintah. Selain daripada itu, partisipasi masyarakat dalam e-government juga dapat berkembang menjadi e-democracy dimana masyarakat dapat berpartisipasi secara langsung melalui media online untuk memilih para pejabat yang duduk di pemerintahan.

\section{4) Meningkatkan Transparansi dan Mengurangi Korupsi}

Dengan menerapkan e-government maka masyarakat dapat mengakses segala informasi tentang pemerintah yang dipublikasikan melalui website seperti publikasi rapat, anggaran dan pengeluaran, dan lainnya. Dengan demikian, e-government turut meningkatkan transparansi dalam pemerintahan sehingga dapat memberantas korupsi serta masyarakat dapat turut melakukan kontrol atas kegiatan di pemerintahan.

\section{d. Tantangan E-Government}

Dalam menerapkan e-government terdapat beberapa tantangan yang harus dihadapi, antara lain: ${ }^{26}$

26 Christhoper G. Reddick, Politics, Democracy, and E-Government: Participation and Service Delivery (New York: IGI Global Snippet, 2011), hlm. 17-39. 
1) Minimnya Peraturan Daerah yang Mengatur Mengenai penerapan E-Government

Dalam rangka menerapkan e-government di setiap daerah maka pemerintah daerah harus menerbitkan peraturan daerah yang mengatur mengenai kewajiban penerapan e-government di daerahnya. Meskipun demikian, masih banyak pemerintah daerah yang belum menerbitkan peraturan daerah tersebut.

2) Belum Ada Tradisi Saling Berbagi Informasi (No Culture of Sharing)

Dalam penerapan e-government maka pemerintah dituntut untuk mempublikasikan seluruh informasi yang dimiliki melalui internet kepada masyarakat. Meskipun demikian, mempublikasikan informasi masih belum menjadi hal yang lazim di kalangan masyarakat Indonesia sehingga banyak oknum pejabat publik yang justru mempersulit masyarakat untuk mendapatkan akses untuk memperoleh informasi tersebut.

3) Belum Ada Tradisi Untuk Mendokumentasi (No Culture of Documenting)

Selain belum ada tradisi untuk berbagi informasi, Indonesia juga menghadapi tantangan dimana para pejabat publik belum terbiasa untuk mendokumentasi segala informasi. Hal ini tentu menghambat penerapan e-government dimana semua informasi harus didokumentasikan dan dipublikasikan.

4) Kurangnya Sumber Daya Manusia yang Handal dan Kemampuan Masyarakat dalam Menggunakan Teknologi

Dalam menerapkan e-government maka dibutuhkan Sumber Daya Manusia yang handal di bidang teknologi informasi. Meskipun demikian, saat ini masih banyak pejabat publik yang tidak memiliki kemampuan yang memadai di bidang teknologi informasi yang mengakibatkan terhambatnya penerapan e-government. Selain itu, tantangan yang dihadapi dari sisi masyarakat ialah masih banyak masyarakat yang belum memahami mengenai penggunaan teknologi.

5) Infrastruktur yang Mahal dan Belum Memadai

Di Indonesia, infrastruktur telekomunikasi masih belum tersebar secara merata bahkan masih banyak warga Negara yang belum dialiri sarana listrik. Hal tersebut tentu membutuhkan banyak investasi dari pemerintah untuk membangun infrastruktur listrik dan telekomunikasi. Meskipun demikian, biaya yang tinggi menghambat pemerintah dalam pembangunan infrastruktur listrik dan telekomunikasi. Dengan demikian, infrastruktur yang belum memadai dan biaya yang mahal menghambat penerapan e-government khususnya di daerah.

\section{6) Akses yang Terbatas}

Dengan minimnya infrastruktur yang memadai membuat akses terhadap e-government menjadi terbatas pada tempat-tempat tertentu saja.

\section{Penerapan E-Government}

United Nations Development Program (UNDP) mendefinisikan bahwa korupsi merupakan penyalahgunaan wewenang sebagai pejabat publik untuk memperkaya diri sendiri melalui penyuapan, gratifikasi, pemerasan, nepotisme, penggelapan, dan pencucian uang. Di Indonesia, ketentuan mengenai korupsi diatur melalui Undang-Undang Nomor 31 Tahun 
1999 jo. Undang-Undang Nomor 20 Tahun 2001 dan memiliki definisi yang serupa dengan UNDP.

Pada dasarnya, korupsi merupakan isu utama dalam suatu pemerintahan yang terjadi akibat kegagalan suatu institusi dan minimnya kemampuan dalam mengorganisir suatu kelompok masyarakat melalui kerangka hukum, politik, sosial, ekonomi, dan check and balances. Lebih lanjut, dalam meminimalisir korupsi, terdapat 4 (empat) strategi yang dapat dilakukan, yaitu:

1) Pencegahan, yakni dengan melakukan reformasi atas prosedur administrasi (dalam perizinan), pencatatan keuangan, dan pelaksanaan pengadaan.

2) Penegakkan hukum, yakni setiap lembaga melakukan pendataan yang benar dan dipublikasikan pada suatu sistem yang efektif untuk dilakukan pengawasan dan penegakkan hukum.

3) Pemberdayaan akses terhadap informasi, yakni adanya akses publik terhadap informasi tentang pemerintah.

4) Peningkatan kapasitas (Capacity Building), yakni memperkuat sistem pemerintahan dan meningkatkan pelatihan untuk para pejabat publik.

Selain strategi di atas maka untuk memberantas korupsi di Indonesia dibutuhkan juga pelaksanaan prinsip-prinsip tata kelola pemerintahan yang baik (good governance). Untuk memaksimalkan pelaksanaan prinsip good governance maka melalui Instruksi Presiden Nomor 3 Tahun 2003 tentang Kebijakan dan Strategi Nasional Pengembangan E-Government mendorong penerapan e-government di seluruh lembaga-lembaga pemerintah baik pusat dan daerah. Adapun dalam penerapan e-government perlu mengintegrasikan 4 (empat) strategi di atas agar pemberantasan korupsi dapat dilakukan secara maksimal.

Pertama, penerapan e-government dapat menjadi upaya untuk pencegahan terhadap korupsi karena dapat memberikan pelayanan dengan prosedur yang sederhana, efektif, efisien, dan mengurangi kontak langsung degan pejabat publik (yang dapat menyalahgunakan wewenang). Meskipun demikian, perlu juga pendidikan kepada masyarakat untuk tidak toleransi terhadap korupsi dan memperkuat nilai-nilai fundamental seperti kejujuran.

Kedua, penerapan e-government juga dapat berperan sebagai bentuk penegakan hukum dan peraturan perundang-undangan untuk memastikan adanya akuntabilitas dan transparansi melalui data yang dipublikasi, tindakan dan keputusan pemerintah yang dipublikasikan, dan adanya mekanisme untuk pemberian saran dan masukan dari masyarakat. Adapun hal ini juga harus didukung dengan reformasi kelembagaan, penguatan dalam peraturan perundang-undangan untuk melindungi "whistleblowers", dan penjatuhan sanksi seberat-beratnya kepada para pihak yang terlibat dalam korupsi.

Ketiga, melalui e-government maka akan tercipta kemudahan dalam mengakses informasi pemerintah oleh masyarakat. Dengan demikian akan tercipta transparansi dan meningkatkan sikap akuntabilitas pemerintah kepada masyarakat atas segala informasi yang disampaikan. Adanya kemudahan dalam mengakses informasi ini juga dapat menjadi kontrol sosial dari masyarakat atas segala tindakan yang dilakukan oleh pemerintah.

Keempat, dalam menerapkan e-government maka harus didukung dengan kapasitas lembaga dan masing-masing individu untuk dapat membangun infrastruktur telekomunikasi, 
perangkat keras (hardware) dan perangkat lunak (software) untuk mendukung aplikasi e-government. Selain daripada itu, dibutuhkan kemampuan sumber daya manusia (dari sisi pemerintah dan masyarakat) yang handal dalam menggunakan teknologi sehingga penerapan e-government dapat semakin efektif.

Banyak Negara mempublikasikan sejumlah informasi untuk menciptakan transparansi melalui e-government seperti di bidang perpajakan, perizinan, pengadaan, dan lainnya, dalam rangka meminimalisir korupsi. Adapun bentuk penerapan e-government dalam meminimalisir korupsi di Indonesia dan Negara lainnya adalah sebagai berikut:

\section{a. Indonesia}

Di Indonesia, penerapan e-government dilakukan dalam berbagai bentuk, sebagai berikut:

\section{1) Pengadaan Barang dan Jasa}

Korupsi terbesar saat ini terjadi dalam pengadaan barang dan jasa. Sekitar 42,70\% atau sebanyak 114 kasus dari total 267 kasus korupsi pada semester II 2013 merupakan kasus pengadaan barang dan jasa. ${ }^{27}$ Adapun karakteristik dari pengadaan barang dan jasa yang menimbulkan penyimpangan dan korupsi antara lain:

a) Bersifat tertutup atau tidak transparan dan tidak diumumkan secara luas, sehingga mengakibatkan para pelaku usaha yang berminat dan memenuhi kualifikasi tidak dapat mengikutinya;

b) Bersifat diskriminatif dan tidak dapat diikuti oleh semua pelaku usaha dengan kompetensi yang sama;

c) Persyaratan dan spesifikasi teknis atau mereknya mengarah kepada pelaku usaha tertentu sehingga menghambat pelaku usaha lain untuk ikut.

Untuk mengatasi masalah tersebut maka peningkatan transparansi serta pengadaan barang dan jasa yang efektif dan efisien diyakini dapat menekan jumlah korupsi. Adapun upaya tersebut dilakukan dengan (i) pengumuman informasi pengadaan barang dan jasa yang dilakukan secara online atau sering disebut dengan e-announcement; dan (ii) pengadaan barang dan jasa pemerintah secara elektronik (e-procurement).

\section{2) Perpajakan}

Untuk meminimalisir korupsi di bidang perpajakan, saat ini telah banyak aplikasi e-government di bidang perpajakan yang diterapkan oleh Direktorat Pajak Republik Indonesia ("Ditjen Pajak"), antara lain sebagai berikut: ${ }^{28}$

a) Situs Internet Ditjen Pajak (http://www. pajak.go.id) yang memuat peraturan perpajakan dan informasi perpajakan.

b) Program Aplikasi Monitoring Pelaporan dan Pembayaran Pajak (MP3) yang berfungsi untuk memonitor dan mengawasi penerimaan pajak secara online.

27 Desi Angriani, "ICW: Korupsi di Pengadaan Barang Masih Mengerikan", 7 Januari 2014, http://microsite. metrotvnews.com/metronews/read/2014/01/07/1/205880/ICW-Korupsi-di-Pengadaan-Barang-masihMengerikan (diakses tanggal 9 Oktober 2014).

28 Direktorat Jenderal Republik Indonesia, “Booklet Ketentuan Umum Perpajakan”, http://www.pajak.go.id/sites/ default/files/BookletKUP.pdf (diakses tanggal 9 Oktober 2014). 
c) Program aplikasi e-registration (e-reg), sistem pendaftaran wajib pajak (untuk memperoleh Nomor Pokok Wajib Pajak) secara online.

d) Program aplikasi e-filing yang merupakan sistem untuk menyampaikan Surat Pemberitahuan Pajak (SPT) secara online.

e) Program aplikasi e-SPT yang merupakan sarana bagi wajib pajak untuk dapat menyampaikan SPT melalui media elektronik.

f) Sistem Informasi Geografis (SIG) yang telah dikembangkan menjadi suatu "smart map" sehingga dapat memuat info rinci yang terkait dengan suatu Nomor Objek Pajak (NOP).

\section{3) Perizinan}

Di bidang perizinan dikenal juga yang namanya perizinan elektronik (e-licensing) guna (i) memberikan kemudahan akses data secara tepat, (ii) meningkatkan efisiensi biaya dan waktu; (iii) proses yang transparan; dan (iv) meminimalisir adanya pungutan liar atau bentuk korupsi lainnya. Secara umum, perizinan elektronik merupakan suatu proses pengajuan izin oleh seseorang/pihak yang dilakukan melalui sistem elektronik (komputerisasi) dimana langkah-langkahnya telah distandarisasi sedemikian rupa sehingga penelaahan, pendataan, serta pemberian izin dapat dilakukan secara cepat, akurat dan transparan. Adapun perizinan elektronik ini banyak diterapkan di bidang pasar modal, penanaman modal, dan lainnya.

\section{b. Korea Selatan}

Untuk meningkatkan transparansi, meminimalisir korupsi pada pelayanan publik, dan mendekatkan pelayanan yang dekat dengan masyarakat, sejak tahun 1998 pemerintah Korea Selatan menerapkan e-government melalui sistem yang dinamakan Online Procedures Enhancement for Civil Applications (OPEN) Initiative. Sistem tersebut memuat seluruh informasi mengenai prosedur pengurusan berbagai macam perizinan beserta dengan nama instansi dan pegawai negeri yang dapat dihubungi sehingga masyarakat dapat mengawasi pelaksanaan pengurusan aplikasi yang diajukan dan dapat mengajukan pertanyaan dalam hal terjadi penyimpangan dalam pengurusan. ${ }^{29}$

\section{India ${ }^{30}$}

Di India, pengembangan e-government dilakukan di Karnataka dan Gujarat dengan mengimplementasikan komputerisasi data pertanahan dan komputerasi pos-pos pengecekan.

Di Karnataka, proyek berlabel "bhoomi" sebagai layanan elektronik data pertanahan memperlihatkan bagaimana database pemerintahan begitu terbuka dan menghindari adanya praktek korupsi oleh petugas pertanahan. Sebelumnya adanya proyek ini, untuk mendapatkan salinan dokumen yang dibutuhkan untuk banyak keperluan semisal pinjaman bank maka petani harus mencari petugas pertanahan di pedesaan yang sulit ditemui karena tugasnya yang terus berkeliling dari satu desa ke desa lain atau

Danilo Piagessi, Kristian Sund, and Walter Castelnovo, Global Strategy and Practice of E-Governance: Examples from Around the World (New York: Information Science Reference, 2011), hlm. 231.

30 Vinay Kumar Bhargava and Emil P. Bolongaita, Challenging Corruption in Asia: Case Studies and a Framework for Action (Washington DC: World Bank, 2013), hlm. 250-257. 
bahkan untuk mempercepat proses tak jarang petani melakukan penyuapan kepada petugas pertanahan tersebut. Setidaknya, dibutuhkan waktu 3-30 hari untuk mendapatkan dokumen tersebut dengan biaya 100-2000 Rupee, tergantung kepentingan dokumen bagi petani dan ukuran tanah. Sementara untuk memperbaharui dokumen dibutuhkan waktu 1-2 tahun.

Akan tetapi dengan adanya proyek Bhoomi, salinan dari dokumen pertanahan dapat diperoleh dengan mengajukan permohonan secara online dengan memasukkan nama pemilik atau nomor persil pada komputer di 180 kantor badan pertanahan dengan biaya hanya 15 Rupee. Meskipun demikian, secara bertahap, database pertanahan mulai di-upload sehingga dapat secara langsung dilihat melalui situs internet.

Dari evaluasi yang dilakukan tim independen, ditemukan bahwa program bhoomi telah meningkatkan layanan pemerintahan dan menekan angka korupsi. Selama periode 12 bulan, terdapat 5,5 juta petani telah membayar 15 Rupee untuk memperoleh salinan data pertanahan sehingga menjadi pemasukan bagi negara sekitar 82,5 juta Rupee atau sekitar Rp. 15 miliar.

Gujarat juga merasakan manfaat pengembangan e-government dengan menghadirkan komputerisasi di sepuluh pos pengecekan antarkota menuju Kota Gujarat. Tujuan pengecekan ialah untuk melakukan inspeksi atas beban muatan truk-truk yang masuk dan validitas dokumen. Jika dibandingkan dengan sistem manual maka hanya ditemukan sekitar dua persen truk yang mengalami kelebihan muatan, namun dengan komputerisasi (termasuk menggunakan jembatan timbang elektronik) maka diketahui bahwa hampir seluruh truk-truk lewat memiliki kelebihan muatan dan dapat langsung dikenakan denda.

Dengan berkurangnya angka korupsi di jembatan timbang tersebut, maka denda yang didapat pun secara signifikan meningkat. Selama tiga tahun uang denda yang didapat hingga mencapai 50 juta Dolar Amerika Serikat. Meskipun demikian, sistem ini tidak lagi dilaksanakan dikarenakan adanya permasalahan antara pemerintah daerah setempat dengan operator swasta di jembatan timbang.

Selain daripada itu, e-government di India juga dimanfaatkan sebagai tempat pengaduan masyarakat terhadap pemerintah melalui complaints.mdconline.gov.id. Aplikasi tersebut dirancang khusus untuk menerima keluhan dari warga masyarakat pada beberapa layanan yang disediakan oleh pemerintah India dan juga untuk menelusuri bagaimana pelayan publik merespon aduan yang disampaikan.

\section{d. Kanada}

Di Kanada, e-government diterapkan dalam satu layanan yang dinamakan Service Canada (Layanan Kanada) yang diciptakan pada tahun 2005. Layanan Kanada merupakan jaringan onestop service yang digunakan oleh warga Kanada untuk mengakses 77 (tujuh puluh tujuh) jenis layanan yang terbagi menjadi 12 (dua belas) bidang pelayanan yang dimiliki oleh Pemerintah Kanada, antara lain di bidang pendidikan, ketenagakerjaan, kesehatan, perumahan, imigrasi, keuangan, hukum, dan lainnya. Adapun layanan Kanada ini bukan hanya dapat diakses melalui halaman situs melainkan juga dari perangkat seluler masyarakat. 
Selain itu, untuk layanan digital signature pada transaksi elektronik maka warga negara Kanada menggunakan e-pass. ${ }^{31}$

\section{e. Singapura}

Di Singapura, e-government diwujudkan dalam bentuk halaman situs yang dinamakan E-Citizen Portal. Melalui situs tersebut, masyarakat dapat mengajukan pertanyaan dan memperoleh jawaban atas pertanyaan serta menjadi portal satu-satunya untuk melakukan segala jenis pengurusan dokumen, seperti passport, akta lahir, dan perizinan-perizinan. Adapun fakta menarik dari penerapan e-government di Singapura ialah warga Negara Singapura harus melakukan pengurusan passport dan akta lahir secara online, apabila dilakukan dengan datang ke departemen yang bersangkutan maka pemohon akan dikenakan penalti. Setelah dikenakan penalti, pemohon tetap harus mengajukan permohonan secara elektronik. ${ }^{32}$

\section{f. Malaysia $^{33}$}

\section{1) Pengadaan Elektronik}

Di Malaysia, penggunaan e-government diterapkan dengan pengadaan elektronik sejak tahun 1999 dalam rangka melakukan pengadaan dan pembelian langsung untuk kebutuhan barang dan jasa pemerintah. Adapun penggunaan pengadaan elektronik dianggap dapat meningkatkan transparansi, menghemat waktu, dan uang.
Penerapan pengadaan elektronik dilakukan melalui www.eperolehan.com. $m y$. Dengan portal tersebut, seluruh calon peserta pengadaan dapat memperoleh dan mengumpulkan dokumen pengadaan. Selain itu, untuk pemasok produk yang telah terpilih akan dilengkapi sebuah smart card untuk dapat melakukan transaksi dengan pemerintah melalui halaman situs.

\section{2) E-Syariah}

Merupakan bentuk penerapan e-government untuk meningkatkan kualitas pelayanan di pengadilan syariah. Melalui portal ini, Islamic Affairs Department dapat melakukan pengawasan dan koordinasi secara efektif serta meningkatkan kualitas atas 102 pengadilan syariah. Adapun aplikasi e-syariah terdiri atas (i) sistem manajemen kasus pengadilan syariah (syariah court case management system); (ii) sistem registrasi konsultan hukum syariah; dan (iii) sistem pengelolaan perpustakaan (library management system).

\section{3) Sistem Pembayaran Elektronik (E-Services)}

Merupakan salah satu bentuk e-government yang dapat digunakan oleh masyarakat untuk melakukan pembayaran utilitas seperti telepon, listrik, jalan tol, dan lainnya. Adapun sistem pembayaran elektronik dapat diakses melalui internet, mesin pembayaran, dan lainnya.

\footnotetext{
31 Leonidas G. Anthopoulos and Christopher G. Riddick, Government e-Strategic Planning and Management: Pratices, Patterns, and Roadmaps (New York: Springer, 2014), hlm. 147-157.

32 Gregory G.Curtin, Michael H. Sommer, and Veronika Vis-Sommer, The World E-Government (New York: Routledge, 2013), hlm. 31-40.

33 Noore Alam Siddiquee, Public Management and Governance in Malaysia: Trends and Transformations (New York: Routledge, 2013), hlm. 168-175.
} 


\section{4) Project Monitoring System}

Merupakan salah satu bentuk e-government yang ditujukan untuk mengawasi implementasi proyek pemerintah yang dilaksanakan melalui berbagai lembaga pemerintah.

\section{5) Pajak Elektronik}

Merupakan aplikasi e-government yang diperkenalkan oleh Internal Revenue Department (“IRD”) sebagai pelayanan pajak elektronik. Dengan menggunakan MyKey digital signature (tanda tangan elektronik), yang ditawarkan oleh MSC Trustgate, seluruh perusahaan dapat menandatangani formulir pajak secara elektronik dan dapat mengirimkan dokumen pajak tersebut secara elektronik ke IRD. Adapun ketentuan mengenai tanda tangan elektronik diatur dalam Malaysia Signature Act 1997.

\section{E. Penutup}

Korupsi merupakan isu utama dalam suatu pemerintahan yang terjadi akibat kegagalan suatu institusi dan minimnya kemampuan dalam mengorganisir suatu kelompok masyarakat melalui kerangka hukum, politik, sosial, ekonomi, dan check and balances. Dalam rangka pemberantasan korupsi di Indonesia maka dibutuhkan pelaksanaan prinsipprinsip tata kelola pemerintahan yang baik (good governance). Untuk memaksimalkan pemberantasan korupsi maka prinsip good governance harus diterapkan melalui konsep e-government yang diintegrasikan dengan 4 (empat) strategi, yakni (i) pencegahan, (ii) penegakan hukum, (iii) pemberdayaan akses terhadap informasi, dan (iv) peningkatan kapasitas. E-government merujuk pada teknologi informasi di lembaga pemerintah atau lembaga publik. Tujuannya adalah agar hubungan dalam tata pemerintahan (governance) yang melibatkan pemerintah, pelaku bisnis dan masyarakat dapat tercipta lebih efisien, efektif, produktif dan responsif. Dengan demikian, hasil yang diperoleh melalui e-government, yaitu terciptanya pemerintahan yang baik korupsi yang berkurang, transparansi yang meningkat, kenyamanan yang lebih besar, peningkatan penerimaan negara, dan/atau pengurangan biaya. Melalui e-government maka hasil yang diperoleh ialah terciptanya pemerintahan yang baik korupsi yang berkurang, transparansi yang meningkat, kenyamanan yang lebih besar, peningkatan penerimaan negara, dan/atau pengurangan biaya.

Di Indonesia, penerapan e-government diwujudkan dalam berbagai bidang untuk meningkatkan efisiensi, efektifitas, transparansi, akuntabilitas, dan prinsip good governance lainnya dalam rangka memberantas korupsi, diantaranya pengadaan barang dan jasa, perpajakan, dan juga perizinan. Meskipun demikian, tahapan pengembangan e-government di Indonesia masih terbatas di interaksi dan masih belum sepenuhnya ke tahap transaksi terlebih ke tahap transformasi mengingat masih banyak pemerintah daerah yang belum menerapkan e-government. Selain di Indonesia, Negara lainnya seperti Korea Selatan, India, Kanada, Singapura, Malaysia juga menerapkan e-government dalam berbagai macam bentuk seperti pembayaran elektronik, komputerisasi data pertanahan, perizinan elektronik, dan lainnya. Adanya penerapan e-government bukan hanya dapat meningkatkan transparansi dan meminimalisir korupsi pada pelayanan publik namun juga mampu menerapkan pelayanan yang dekat dengan masyarakat. 
Untuk dapat menerapkan e-government secara efektif dalam memberantas korupsi maka disarankan pemerintah Indonesia harus melaksanakan strategi percepatan pembuatan peraturan perundang-undangan dan kebijakan untuk mendukung e-government di daerah; pengadaan sarana-prasarana pengembangan infrastruktur untuk menciptakan akses komunikasi data yang handal; pemberdayaan sumber daya manusia dan/atau kerja sama dengan swasta/masyarakat dalam penyediaan akses komunikasi data yang mudah, nyaman, dan dengan biaya terjangkau; pengembangan sumber daya manusia dalam pengelolaan dan penggunaan E-Government; pengembangan perangkat-perangkat lunak yang diperlukan; dan pengembangan organisasi dan tata kerja yang mendukung e-government.

\section{DAFTAR PUSTAKA}

\section{BUKU}

Anthopoulos, Leonidas G. and Christopher G. Riddick, Government e-Strategic Planning and Management: Pratices, Patterns, and Roadmaps (New York: Springer, 2014).

Bhargava, Vinay Kumar and Emil P. Bolongaita, Challenging Corruption in Asia: Case Studies and a Framework for Action (Washington DC: World Bank, 2013).

Charron, Nicholas, Victor Lapuente, andBo Rothstein, Quality of Government and Corruption from a European Perspective: A Comparative Study of Good Government in EU Regions (United Kingdom: Edward Elgar Publishing Limited, 2013).

Cools, Marc et.al., EU Criminal Justice, Financial, and Economic Crime (Poland: Maklu Publishers, 2011).

Curtin, Gregory G., Michael H. Sommer, and Veronika Vis-Sommer, The World E-Government (New York: Routledge, 2013).

Forsythe, Clarke D., Abuse of Discretion: The Inside Story of Roe v. Wade (New York: Wilsted \& Taylor Publishing Services, 2013).
Gil-Garcia, J. Ramon, Enacting Electronic Government Success: An Integrative Study of Governmentwide Websites, Organizational Capabilities, and Institutions (New York: Springer, 2012).

International, Transparency, Corruption Perceptions Index 2013 (Berlin: Transparency International, 2013).

Ionas, Alexandru, Proceedings of the $14^{\text {th }}$ European Conference on E-Government (United Kingdom: Academic Conferences and Publishing International Limited, 2014).

Kaufmann, D., A. Kraay, and M. Mastruzzi, Governance Matters VIII: Aggregate and Individual Governance Indicators, 1996-2008 (United States: Development Research Group Macroeconomics and Growth Team The World Bank: 2010).

Klitgaard, Robert, Corruption and Government: Causes, Consequences, and Reform (Cambridge: Cambridge University Press, 2012).

Klun, Maja, et.al., Proceedings of the $11^{\text {th }}$ European Conference on E-Government (United Kingdom: Academic Conferences and Publishing International Limited, 2011).

Loukis, Euripidis, Ann Macintosh, and Yannis Charalabidis, E-Participation in Souther Europe and The Balkans (New York: Routledge, 2013).

Mahmood, Zaigham, E-Government Implementation and Practice in Developing Countries (United States: Information Science Reference, 2013).

Margolis, Michael and Gerson Moreno-Riano, The Prospect of Internet Democracy (England: Ashgate Publishing Limited: 2013).

Mendilow, Jonathan, Money, Corruption, and Political Competition in Established and Emerging Democracies (United Kingdom: Lexington Books, 2012).

Nixon, Paul G., Vassiliki N. Koutrakou, and Rajash Rawal, Understanding E-Government in Europe: Issues and Challenges, (New York: Routridge, 2010).

OECD, OECD E-Government Studies: Egypt 2012 (Egypt: OECD Publishing, 2013).

Paul. Samuel, Who Will Bell the Cat? (Bangalore: Public Affairs Centre, 2012).

Piagessi, Danilo, Kristian Sund, and Walter Castelnovo, Global Strategy and Practice of E-Governance: Examples from Around the World (New York: Information Science Reference, 2011). 
Reddick, Christhoper G. Politics, Democracy, and E-Government: Participation and Service Delivery (New York: IGI Global Snippet, 2011).

Schalaeger, Jesper, E-Government in China: Technology, Power, and Local Government Reform (New York: Routledge, 2013).

Shareef, Mahmud Akhter, Stakeholder Adoption of E-Government Services: Driving and Resisting Factors (New York: IGI Global Snippet, 2011).

Shareef, Mahmud Akhter et.al., Transformational Government Through eGov Practice: Socioeconomic, Cultural, and Technological Issues (United Kingdom: Emerald Group Publishing Limited, 2012).

Siddiquee, Noore Alam, Public Management and Governance in Malaysia: Trends and Transformations (New York: Routledge, 2013).

Snellen, M., M. Thaens, and J.van de Honk, Public Administration in The Information Age: Revisited (Netherlands: IOS Press BV, 2012).

United Nations, United Nations E-Government Survey 2014: E-Government for the Future We Want (New York: Bern Assoc, 2014).

Vazquez, J. Martinez, Arze del Granado, and J. Boex, Fighting Corruption in The Public Sector (London: Elsevier, 2012).
Zemanovicova, Economic Aspects of Corruption (United Kingdom: Oxford University Press, 2013).

\section{MAKALAH/ARTIKEL/HASIL PENELITIAN}

Fath-Allah, Abdoullah, et.al., "E-Government Maturity Models: A Comparative Study", International Journal of Software Engineering and Applications (IJSEA) 5 (2014).

Singla, Sushil Kumar and Himanshu Anggarwal, "Combating Corruption Through E-Governance in Public Service Delivery System," Journal of Global Research in Computer Science 2 (2011).

\section{INTERNET}

Desi Angriani, "ICW: Korupsi di Pengadaan Barang Masih Mengerikan", 7 Januari 2014, http:// microsite.metrotvnews.com/metronews/ $\mathrm{read} / 2014 / 01 / 07 / 1 / 205880 / / C W-K o r u p s i-d i-$ Pengadaan-Barang-masih-Mengerikan (diakses tanggal 9 Oktober 2014).

Direktorat Jenderal Republik Indonesia, "Booklet Ketentuan Umum Perpajakan", http://www. pajak.go.id/sites/default/files/BookletKUP.pdf (diakses tanggal 9 Oktober 2014). 